UDC 66.048.5.022.63:564.849

DOI: 10.15587/2706-5448.2021.242162

Article type «Reports on Research Projects»

\section{Aleksey Zagorulko, \\ Oleksander Cherevko, Andrii Zahorulko, Marina Yancheva, Mariana Bondar, Svetlana Dudnyk}

\title{
IMPROVEMENT OF THE METHOD FOR PRODUCING COMFITURES FROM FRUIT RAW MATERIALS
}

The object of research is the method of production of comfiture from fruit and vegetable raw materials. The production of comfiture using traditional technologies is characterized by the loss of physiologically functional ingredients of raw materials. Such losses can reach up to $60 \%$ of the initial amount, depending on the temperature regime and the duration of heat treatment. A negative factor in the storage of ready-made comfitures is sugar crystallization. Equipment for the implementation of traditional processes of processing fruits and vegetables is characterized by high productivity, low efficiency and operational difficulties.

Boiling in the traditional way is carried out at high-temperature conditions, which leads to a decrease in the content of functionally physiological ingredients and the nutritional value of the resulting comfitures. In the production of comfiture on the basis of fruit and vegetable raw materials, the following recipe ratio of components was used: apple - $60 \%$; Jerusalem artichoke - $25 \%$; cornelian cherry - $15 \%$. The improved method is characterized by gentle heat exchange operations, in particular: drying is carried out in an infrared dryer at a temperature of $40-50{ }^{\circ} \mathrm{C}$ to a dry matter content of 30-40\%. And also by further boiling of the mass in a vacuum evaporator based on a flexible film resistive radiating electric heater (FFRREH) at $50-60^{\circ} \mathrm{C}$. The use of inverted syrup in the recipe during boiling prevents sugar crystallization during storage of the finished product. Comparative analysis of the heating kinetics of comfiture from fruit and vegetable raw materials confirms the reduction in the duration of reaching the stationary mode $\left(55^{\circ} \mathrm{C}\right)$ when using a vacuum evaporator based on FFRREH by 1.6 times, compared with an analog apparatus. Such a hardware-constructive solution will ensure a decrease in the consumption of energy resources with a simultaneous increase in the quality characteristics of products.

Keywords: comfiture production, drying in an infrared dryer, fruit and vegetable raw materials, mass boiling, vacuum evaporator.

Zagorulko, A., Cherevko, O., Zahorulko, A., Yancheva, M., Bondar, M., Dudnyk, S. (2021). Improvement of the method for producing comfitures from fruit raw materials. Technology Audit and Production Reserves, 5 (3 (61)), 26-28. doi: http://doi.org/10.15587/2706-5448.2021.242162

\section{Introduction}

Recently, there has been a growing demand for high quality concentrated food products. Such products have high functional and technological properties due to the presence of natural components in the recipe composition [1, 2]. Highviscosity concentrated products have more compact overall dimensions from the initial volume, so the unit costs for their transportation are minimal. The production of such products is usually low-waste. Concentrated products are made from fruits and berries or semi-finished fruits and vegetables (mashed potatoes, pasta) by boiling with sugar syrup and auxiliary raw materials (structure formers, food acids, flavorings, etc.) to the required dry matter content. At the same time, the addition of sugar syrup gives the product pleasant taste and nutritional value, and also acts as a preservative, since the vital activity of microorganisms decreases, namely, moisture is quickly removed from their cells, and they die.
Concentrated food products and semi-finished products from fruit and vegetable raw materials [3] produced by knitting, as a rule, have a long shelf life - from 7 to 15 months or more, due to the increased content of dry substances and the presence of organic acids. Currently, the produced assortment of concentrated food products from fruits and vegetables has a fairly wide assortment [3, 4]. Concentrated products include fruit and berry and fruit and vegetable purees, pastes, sauces, including for baby food, fruit and berry jelly, comfiture, marshmallow, marmalade, preserves, candied fruits, comfitures, etc.

Confirming the relevance of improving technologies for the production of health food products based on natural substances with functionally physiological ingredients to increase the nutritional and biological value of finished products, in particular, comfitures. Analysis of the existing methods of production of comfiture allowed to form ways to improve the production of comfiture with increased 
nutritional value, which is lost during processing using low-resource-efficient equipment and high-temperature heat exchange modes [5-7]. Taking into account the existing shortcomings, an urgent task is to improve the method of production of comfiture using raw fruits and vegetables with the maximum preservation of natural biologically active substances due to gentle heat treatment $[8,9]$.

The object of research is the method of production of comfiture from fruit and vegetable raw materials. The aim of research is to develop an effective method for the production of comfiture from fruit and vegetable raw materials.

\section{Methods of research}

For experimental studies, when creating the recipe composition of the comfiture, ripe fruit and vegetable raw materials were used for example: apple, Jerusalem artichoke and cornelian cherry. The content of each proposed raw material was substantiated by making three compositions of prototypes with varying components, followed by blending into a homogeneous puree-like mass. The proposed content of raw materials when creating comfiture changed as follows (per $100 \mathrm{~g}$ of product): apple - 55-65 g; Jerusalem artichoke - 25-35 g; cornelian cherry - 5-15 g.

The prepared compositions of prototypes according to the structural-mechanical, physicochemical and organoleptic indicators made it possible to identify the optimal recipe composition with the content: apples $-60 \%$; Jerusalem artichoke $-25 \%$; cornelian cherry $-15 \%$. For the static probability, the experimental studies were carried out in a fivefold repetition. The operating parameters of the processes of infrared (IR) drying and concentration were carried out according to the classical method of studying heat exchange processes.

To study the duration of reaching a stationary heating mode during heat treatment of comfiture samples, a model design of an improved vacuum evaporator with a control and measuring complex «OVEN» (Ukraine) was used. The automatic complex «Aries» allows to get in real time in graphic interpretation, in particular, the temperature curves of the acceleration of the transient process.

\section{Research results and discussion}

During boiling in the traditional way, as a rule, a hightemperature regime is used, which helps to reduce the content of functionally physiological ingredients and reduces the nutritional value of the resulting product. Also, in the process of further storage of the packaged comfiture, sugar crystallization occurs over time, which is a negative phenomenon.

The solution to these disadvantages is the improvement of the method for the production of comfiture by using gentle temperature modes of IR-drying and concentration in inverted syrup, which will increase the biological value and taste characteristics. The introduction of inverted syrup prevents sugar crystallization during storage, and the use of innovative equipment will increase the efficiency of the process by reducing the duration of the jelly production process.

An improved method of comfiture is carried out as follows. Fresh fruits and vegetables are inspected immediately, after which they are sent for drying at a temperature of $40-50{ }^{\circ} \mathrm{C}$ to a dry matter content of $30-40 \%$ in a universal infrared dryer [10]. To create the comfiture, the following recipe composition of raw materials was chosen: apple - $60 \%$; Jerusalem artichoke - $25 \%$; cornelian cherry - $15 \%$.

The selected fruit and vegetable raw materials allow to enrich the manufactured comfiture with physiologically functional ingredients, namely pectin and tannins, vitamins, polyphenols, and the like. The resulting products are distinguished by a rich aroma and taste of fresh apples and cornelian cherry fruits, as well as a pleasant appearance.

Dried fruit and vegetable raw materials are crushed in a crusher to a particle size of $1.2-2.5 \mathrm{~mm}$ and sent to the vacuum of the evaporator, where they are mixed to a homogeneous mass with inverted sugar syrup, tartaric acid and aromatic components. The resulting mass is boiled at a temperature of $50-60{ }^{\circ} \mathrm{C}$ to a dry matter content of $60-75 \%$ for $5-8$ minutes. The resulting comfiture is pasteurized in a stream at a temperature of $70-75{ }^{\circ} \mathrm{C}$ and sent for packing in sterilized glass jars.

The comfiture made in this way has a strong homogeneous structure, a pleasant rich taste of fruit and vegetable fillings with an attractive red-burgundy color. Using the proposed method will increase the biological value and organoleptic characteristics of the finished comfiture due to the presence in it of natural pectins, polyphenols, vitamins and microelements, etc.

Mixing of the components of the recipe mixture based on fruit and vegetable raw materials with subsequent concentration of the mass is realized in a vacuum evaporator with heating of the working surface and stirrer with a flexible film resistive radiating electric heater (FFRREH). To confirm the efficiency of boiling in an apparatus based on FFRREH, the duration of reaching a stationary mode when heating the prototypes of comfiture is shown in comparison with a traditional evaporating apparatus of the MZS-320 brand, Ukraine (Fig. 1).

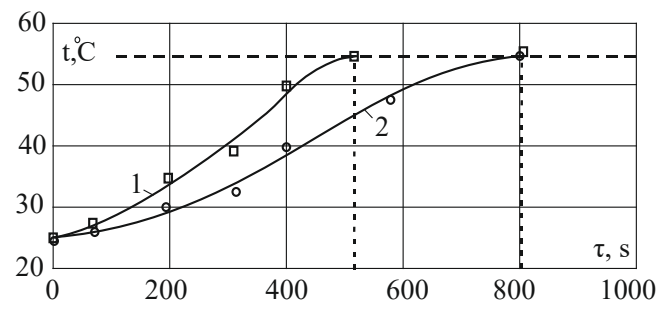

Fig. 1. Duration of reaching the stationary mode ( $\left.55^{\circ} \mathrm{C}\right)$ when the comfiture is heated: 1 - in a model sample of a vacuum evaporator with FFRREH; 2 - vacuum evaporator MZ5-320

An analysis of the duration of reaching a stationary heating mode confirms the effectiveness of using a model design of a vacuum evaporator based on FFRREH and amounts to $510 \mathrm{~s}$, which is 1.6 times less than the analogue of MID-320 (805 s). The use of FFRREH in the model design of a vacuum evaporator makes it possible to eliminate a steam-water jacket and steam fittings from the design of a traditional evaporator. The proposed hardware and technological solution for the production of comfiture will provide an increase in the quality of finished products by reducing the duration of reaching a stationary mode, sparing temperature conditions and, in general, the efficiency of the process. This approach to solving the design of heating the working chamber of the evaporator allows to reduce energy consumption, the heating time of the product and can be used to improve the thermal equipment of the entire complex of equipment in the line for 
the production of various products from vegetable raw materials. One of the limitations of the study is the significant influence of each component of the blend with its original organoleptic and structural-mechanical properties, which requires rational selection of plant raw materials. Failure to comply with heat exchange parameters from lowtemperature IR-drying, concentration and recipe ratios of components will lead to a change in the original properties of the finished product. Further research will be aimed at intensifying the hardware and technological complex for increasing the efficiency of the comfiture production line through the use of energy-saving complexes.

\section{Conclusions}

The method for the comfiture production has been improved, with the justification for the selection of fruit and vegetable raw materials on the basis of: apples $-60 \%$; Jerusalem artichoke - $25 \%$; cornelian cherry - $15 \%$. The method is characterized by gentle heat exchange operations, in particular: drying in an IR dryer at a temperature of $40-50{ }^{\circ} \mathrm{C}$ to a dry matter content of $30-40 \%$ and further boiling of the mass in vacuum evaporators based on FFRREH $\left(50-60{ }^{\circ} \mathrm{C}\right)$. The duration of reaching a stationary heating mode up to $55^{\circ} \mathrm{C}$ of a model design of a vacuum evaporator based on FFRREH is $510 \mathrm{~s}$, which is 1.6 times less compared to an analog device (805 s). At the same time, the use of inverted syrup in the recipe during boiling prevents sugar crystallization during storage of the finished product. Such a hardware-constructive solution will ensure a decrease in the consumption of energy resources with a simultaneous increase in the quality characteristics of products by reducing the duration of reaching a stationary regime and sparing temperature regimes.

\section{References}

1. Del Río-Celestino, M., Font, R. (2020). The Health Benefits of Fruits and Vegetables. Foods, 9 (3), 369. doi: https://doi.org/ $10.3390 /$ foods 9030369

2. Bogatyrev, A. N., Pryanichnikova, N. S., Makeeva, I. A. (2017) Natural food - health of the nation. Pischevaya promyshlennost', 8, 26-29. Available at: https://cyberleninka.ru/article/n/ naturalnye-produkty-pitaniya-zdorovie-natsii

3. Percival, S. S. (2011). Nutrition and Immunity. Nutrition Today, 46 (1), 12-17. doi: https://doi.org/10.1097/nt.0b013e3182076fc8

4. Golubtsova, Y. V., Prosekov, A. Y., Moskvina, N. A. (2019). Identification of fruits and berries raw materials in multicomponent food systems. Dairy Industry, 3, 28-29. doi: https:// doi.org/10.31515/1019-8946-2019-3-28-29
5. Kupin, G. A., Pershakova, T. V., Gorlov, S. M., Victorova, E. P., Matvienko, A. N., Velikanova, E. V. (2017). Investigation of the influence of fruit treatment with electromagnetic fields of extremely low frequency and bio-preparations on the loss of biologically active substances in the process of storing. Scientific Journal of KubSAU, 132. doi: https://doi.org/10.21515/1990-4665-132-087

6. Sukhenko, Yu. H., Mushtruk, M. M., Sarana, V. V.; Sukhenko, Yu. H. (Ed.) (2017). Zabezpechennia dovhovichnosti obladnannia kharchovykh $i$ pererobnykh pidpryiemstv. Kyiv: TsP «KOMPRYNT», 462.

7. Gayazova, A. O., Prohas'ko, L. S., Popova, M. A., Lukinyh, S. V., Asenova, B. K. (2014). Ispol'zovanie vtorichnogo i rastitel'nogo syr'ya v produktah funktsional'nogo naznacheniya. Molodoy ucheniy, 19, 189-191.

8. Derevitskaya, O. K., Dydykin, A. S., Ustinova, A. V., Aslanova, M. A. (2016). New standards for canned baby food. Pischevaya promyshlennost', 1, 22-25.

9. Zagorulko, A., Zahorulko, A., Kasabova, K., Chervonyi, V., Omelchenko, O., Sabadash, S. et. al. (2018). Universal multifunctional device for heat and mass exchange processes during organic raw material processing. Eastern-European Journal of Enterprise Technologies, 6 (1 (96)), 47-54. doi: https://doi.org/ 10.15587/1729-4061.2018.148443

10. Cherevko, A., Kiptelaya, L., Mikhaylov, V., Zagorulko, A., Zagorulko, A. (2015). Development of energy-efficient IR dryer for plant raw materials. Eastern-European Journal of Enterprise Technologies, 4 (8 (76)), 36-41. doi: https://doi.org/10.15587/17294061.2015.47777

Aleksey Zagorulko, PhD, Associate Professor, Department of Equip ment and Engineering of Processing and Food Production, State Biotechnological University, Kharkiv, Ukraine, ORCID: http://orcid.org/ 0000-0003-1186-3832

Oleksander Cherevko, Doctor of Technical Sciences, Professor, De partment of Processes and Equipment Food and Hospitality-Restaurant Industry named after M. Belaev, State Biotechnological University, Kharkiv, Ukraine, ORCID: https://orcid.org/0000-0002-3424-8659

$\triangle$ Andrii Zahorulko, PhD, Associate Professor, Department of Equipment and Engineering of Processing and Food Production, State Biotechnological University, Kharkiv, Ukraine, ORCID: http:// orcid.org/0000-0001-7768-6571,e-mail: zagorulkoAN@hduht.edu.ua

Marina Yancheva, Doctor of Technical Sciences, Professor, Department of Meat Technology, State Biotechnological University, Kharkiv, Ukraine, ORCID: http://orcid.org/0000-0002-6143-529X

Mariana Bondar, Assistant, Department of Food Technologies and Microbiology, Vinnytsia National Agrarian University, Vinnytsia, Ukraine, ORCID: https://orcid.org/0000-0001-8154-0612

Svetlana Dudnyk, Assistant Professor, Department of Hotel, Restaurant and Resort Industry, Higher Educational Institution of Ukoopspilka «Poltava University of Economics and Trade», Poltava Ukraine, ORCID: https://orcid.org/0000-0001-8228-7276

$\triangle$ Corresponding author 